\title{
Computation of Theoretical Heat of Formation in a Kiln Using Fortran Language
}

\author{
Dr. Isa Garba \\ Department of Mechanical Engineering Bayero University, Kano
}

\begin{abstract}
The evolution of the early rotary kiln for cement industries and innovation made by man is to ease cement processing. The rotary Kiln in which cement is burnt at $1300^{\circ} \mathrm{C}$ to $1550^{\circ} \mathrm{C}$ is a long cylinder rotating on its axis and inclined so that the materials fed in at the upper end travel slowly to the lower end.

The approach adopted is by evolving a mathematical model of the system. Simulation of the process was carried out using FORTRAN language to compute theoretical heat of formation. The exact value of theoretical heat of formation was found to be 435.583000 .

The aim is to produce a good quality clinker at the optimum fuel consumption and thermal efficiency.

The computer model is in a FORTRAN language. The simulation provides very encouraging result, which showed trends that enabled the deduction of optimum system parameters.

Significance: This paper investigated the behavior of the kiln through computer simulations, for comparing the performance of different constitutions under similar operations and conditions. The paper highlighted how a good quality clinker can be produced at optimum fuel consumption and thermal efficiency.
\end{abstract}

Keywords: simulation, kiln, constituents, mathematical model, clinker and Theoretical heat

\section{Introduction}

Kiln is a device or enclosure to provide thermal processing of an article or substance in a controlled temperature environment or atmosphere, often by direct firing, but occasionally by convection or radiation heat transfer. Kiln usually refers to an over or furnace which operates at sufficiently high temperature. Generally the word kiln is used when referring high-temperature treatment of non-metallic materials such as wood, ceramic, the cement and the lime industries. Kilns are used in different industries, and the type of device called a kiln varies with the industry. In the rotary kiln, the raw meal temperature is raised so that the chemical reaction that leads to the formation of cement clinker can take place.

Portland cement types are essentially composed of Tricalcium silicate $\left(\mathrm{C}_{3} \mathrm{~S}\right)$; Dicalcium silicate $\left(\mathrm{C}_{2} \mathrm{O}\right)$, tricalcium aluminate $\left(\mathrm{C}_{3} \mathrm{~A}\right)$ and tetracalcium aluminoferrite $\left(\mathrm{C}_{4} \mathrm{AlFe}\right)$. Presence of more or less of the above constisstuents in the Portland cement imparts the different properties required of the different types of cement. The range of these constituent in Portland cement types is given in Table 1.

Table 1: Range of Chemical composition of Portland Cement

\begin{tabular}{|c|c|}
\hline CONSTITUTIONS & RANGE \\
\hline $\mathrm{S}_{\mathrm{i}} \mathrm{O}_{2}$ & 19 to $25 \%$ \\
\hline $\mathrm{Al}_{2} \mathrm{O}_{3}$ & 2 to $8 \%$ \\
\hline $\mathrm{Fe}_{2} \mathrm{O}_{3}$ & 0.3 to $6 \%$ \\
\hline $\mathrm{CaO}$ & 60 to $65 \%$ \\
\hline $\mathrm{MgO}$ & 1 to $6 \%$ \\
\hline $\mathrm{SO}_{2}$ & 1 to $3 \%$ \\
\hline $\mathrm{Alkalis}$ & 0.5 to $1.5 \%$ \\
\hline
\end{tabular}

\section{Materials And Methods}

\section{Methodology}

Results from computer simulation models are very helpful for system design since they allow one to learn about the complex interaction of a large number of variables in a short time whereas physical experiments are time consuming and costly. Therefore, the methodology involves:

i) Review of past work on both experimental heat transfer processes and direct analytical method.

ii) Heat transfer analysis of a kiln to provide the theoretical considerations on which the design calculations are based.

iii) System simulation: modeling of the system to determine system and sub-system technical performance.

iv) Discussion of results, conclusions and recommendations. 


\subsection{THEORETICALANALYSIS}

\section{2-1 HEAT INPUT}

The heat input comes from the following:

1) Oil combustion sensible heat

2) From feed - combustion of organic sensible heat

3) Air - sensible heat

\section{2-2 HEAT OUTPUT}

The heat output comes from the following:
1) Theoretical heat
2) Evaporation of water combined in the material
3) Combustion gas steam water
4) Sensible heat in exhaust gases
5) Exhaust air from cooler
6) Sensible heat of linker dust loss
7) Heat loss due to incomplete combustion

8)

The exit gases are as follows: $\mathrm{CO}_{2}, \mathrm{~N}_{2}, \mathrm{CO} 2, \mathrm{CO}, \mathrm{SO}_{2}, \mathrm{H}_{2} \mathrm{O}$ and Water vapor. The quantity of heat loss accompanying each of these gases must be calculated.

1) Heat of formation of clinker: This is the heat to convert the raw material to clinker. This is termed the theoretical heat of formation of the raw meal, from first principles by using heat of reaction data.

A more rapid estimation of this heat can be done by using a formula developed by Zur Strassen (1957) which gives good agreement with basic calculations. This formula is:

$\mathrm{Q}_{\mathrm{th}}=2.22 \mathrm{~A}+7.64 \mathrm{C}-5.116 \mathrm{~S}-0.59 \mathrm{~F}$

Where $\mathrm{Q}_{\mathrm{th}}=$ theoretical heat of the formation

$\mathrm{A}, \mathrm{M}, \mathrm{C}, \mathrm{S}$ and $\mathrm{F}$ are the percentage of $\mathrm{AW}_{3}, \mathrm{MgO}, \mathrm{CaO}, \mathrm{SiO}_{2}$, and $\mathrm{Fe}_{2} \mathrm{O}$ in the clinker.

Calculation Of Exit Gas Loss

\section{Results And Discussion}

Taking the following operating data:

Back end Temperature

Datum Temperature

Temperature difference

Table 2: Exit Gas Loss

\begin{tabular}{|l|l|l|l|l|}
\hline Gas & $\begin{array}{l}\text { Kg of Gas per } \\
\text { Kg of Clinker }\end{array}$ & $\begin{array}{l}\text { Specific Heat } \\
\text { Kcal } / \mathrm{Kg}{ }^{\circ} \mathrm{C}\end{array}$ & $\begin{array}{l}\text { Temperature } \\
\text { Differences }{ }^{\circ} \mathrm{C}\end{array}$ & Heat Loss Kcal \\
\hline $\mathrm{CO} 2$ & 1.2450 & 0.222 & 192 & 53.06 \\
\hline $\mathrm{SO} 2$ & 0.0076 & 0.150 & 192 & 0.22 \\
\hline $\mathrm{O} 2$ & 0.0274 & 0.223 & 192 & 1.17 \\
\hline $\mathrm{N} 2$ & 2.0638 & 0.249 & 192 & 98.67 \\
\hline Water Vapour & 0.3023 & 0.452 & 192 & 24.38 \\
\hline Excess Fuel & 0.3230 & 586 Latent heat & - & 177.15 \\
\hline Water Vapour & 0.8670 & 0.452 & 192 & 75.24 \\
\hline Excess Slurry & 0.8670 & 586 Latent heat & - & 508.06 \\
\hline Total & & & & 937.95 \\
\hline
\end{tabular}

PROGRAM TO COMPUTE THE THEORETICAL HEAT OF FORMATION

A.M.C.S.F are the percentages of A1203, $\mathrm{MgO}, \mathrm{CaO}, \mathrm{SiO}_{2}, \mathrm{Fe}_{2} \mathrm{O}_{3}$

Feal M1

Open $(3$, file $=$ "Heat Out")

$\mathrm{S} 1=19$

$\mathrm{A} 1=2$

$\mathrm{F} 1=0.3$

$\mathrm{C} 1=60$

$\mathrm{M}=1$

Write (3.80) 
80 Format (I.15x, "Computation of Theoretical Heat Formation")

Write (3.85)

$85 \quad$ Format $(I .15 \mathrm{x}$ “

Write (3.125)

125 Format (III.10x, "Initial Values of S.A.F.C")

Write (3.130)

130 Format $(10 \mathrm{x}$,

Write (3.120) S1, A1, F1, C1, M1

120 Format $(1.7 \times 5(\mathrm{~F} 5,2.2 \mathrm{x}))$

Write (3.135)

135 Format (III, "ITER,", 4x

"SIO2", 5x, "AIO3, 7x, "FeO3', 7x, "CaO", 7x, "MgO", 7x, "Qth")

Write (3.140)

140 Format (" $===", 5 \mathrm{x}$

"===", 5x, "===+, 7x, " ===", 7x, "===", 7x, "===", 7x, "===")

DELTA $=0.05$

$\mathrm{K}=1$

$150 \quad \mathrm{~S} 1=\mathrm{S} 1+$ Delta

$\mathrm{A} 1=\mathrm{A} 1+$ Delta

$\mathrm{F} 1=\mathrm{F} 1+$ Delta

$\mathrm{C} 1=\mathrm{C} 1+$ Delta

$\mathrm{M} 1=\mathrm{M} 1+$ Delta

If $(\mathrm{A} 1>8.0000)$ go to 200

$\mathrm{Q}_{\mathrm{th}}=2.2 * \mathrm{~A} 1+6.48 * \mathrm{M} 1+7.64 * \mathrm{C} 1-5.116 * \mathrm{~S} 1-0.59 * \mathrm{~F} 1$

Write (3.100) K.S1, A1, F1, C1, M1, Qth

100 Format $(I I, 13.2 \mathrm{x}, 5(\mathrm{~F} 8.4,2 \mathrm{x}), 2 \mathrm{x}, \mathrm{F} 10.5)$

Table 3: COMPUTATION OF THEORETICAL HEAT FORMATION

\begin{tabular}{|c|c|c|c|c|c|c|}
\hline \multirow[b]{2}{*}{19.00} & \multicolumn{6}{|c|}{ INITIAL VALUES OF S.A.F.C } \\
\hline & 2.00 & .36 & & 60.00 & 1.00 & \\
\hline Item & $\mathrm{SiO}_{2}$ & $\mathrm{AlO}_{2}$ & $\mathrm{FeO}_{3}$ & $\mathrm{CaO}$ & MgO & $\mathbf{Q}_{\text {th }}$ \\
\hline 1. & 19.0500 & 2.0500 & .3500 & 60.0500 & 1.0500 & 372.42970 \\
\hline 2. & 19.1000 & 2.1000 & .4000 & 60.1000 & 1.1000 & 372.96040 \\
\hline 3. & 19.1500 & 2.1500 & .4500 & 60.1500 & 1.1500 & 373.49110 \\
\hline 4. & 19.2000 & 2.2000 & .5000 & 60.2000 & 1.2000 & 374.55250 \\
\hline 5. & 19.2500 & 2.2500 & .5500 & 60.2500 & 1.2500 & 374.55250 \\
\hline 6. & 19.3000 & 2.3000 & .6000 & 60.3000 & 1.3000 & 375.08320 \\
\hline 7. & 19.3500 & 2.3500 & .6500 & 60.3500 & 1.3500 & 375.61390 \\
\hline 8. & 19.4000 & 2.4000 & .7000 & 60.4000 & 1.4000 & 376.14460 \\
\hline 9. & 19.4500 & 2.4500 & .7500 & 60.4500 & 1.4500 & 376.67530 \\
\hline 10. & 19.5000 & 2.5000 & .8000 & 60.5000 & 1.5000 & 277.20600 \\
\hline 11. & 19.5500 & 2.5500 & .8500 & 60.5500 & 1.5500 & 377.73670 \\
\hline 12. & 19.6000 & 2.6000 & .9000 & 60.6000 & 1.6000 & 378.26740 \\
\hline
\end{tabular}

\section{Conclusion}

This work on simulation studies was carried out with a view to determining the exact percentages of each constituent needed for the production of good quality clinker.

A computer program using the component model method was developed.

The program had been shown to be capable of the long-term system performance of the kiln.

The result of the simulations was presented in Table 3 . This work was perceived because of the fact that techno economic viability of kiln can only be assessed based on long-term performance predictions.

The simulation provides very encouraging results which showed trends that will enable the deduction' of optimum system parameters. At a temperature of $145^{\circ} \mathrm{C}$, the fuel savings is $0.33560 \mathrm{Kg} / \mathrm{s}$ and the annual fuel saving is 10599724 . $80 \mathrm{Kg}$. This is equivalent to \# 63,594,324.73 in monetary terms.

For every $1^{0} \mathrm{C}$ fall in the flue gas temperature the fuel savings is $0.0111156 \mathrm{Kg} / \mathrm{s}$ or an annual fuel savings of $46500.5 \mathrm{Kg}$. 


\section{Simulated Results}

Studies of the type undertaken in this paper are quite complex, since simulating the system at desired input condition and then drawing the necessary conclusions after having made a proper analysis must be carried out.

However, the problem is made easier since kiln model exist, one needs only to make some refinement, to suit the requirements. On the whole, however, there is the need to conduct further investigations of the system in order to enable us have more confidence in drawing conclusions. It is therefore recommended that:

Make further refinement on the model. The success of this study depends on the validity of the system model.

With the emergence of technology and the growing desire for more cement, creation of new ideas on how best to improve the heating process is of prime importance to most cement manufacturers.

This does not merely refer to heating in the kiln alone, but includes effective heating process that involves less cost. Tree importance precautions must be taken while using the shaft kiln process:

The coal must be low volatile.

The raw mix to be used must be fairly plastic so that the modules when dry are strong and do not break in the kiln.

Because of $100 \%$ ash absorption the carbonates of the raw mi should be higher than that used in rotary kiln process. In order to gain cementations properties and make the resultant cement more suitable for certain jobs, certain natural or man-made inorganic complexes must be added to

Portland cements clinker (or lime) and ground finely. These complexes are pozzolanas, slags and limestone. For better efficiency in kiln burning technique, computer control of preparation of the raw mix and operation of the kiln department is to be established.

\section{References}

[1]. Richard C. D (1989) "Energy resources and Policy”. Addison - Wesley Publishing Company

[2]. Scott P. J. and Homes J. R (1986) "Heat utilization at Coventry Waste Reduction Unit" Chartered Min. Eng. Vol. 103 pp. 8 - 12.

[3]. Stambulearn A. S. (1994) "Flame Combustion process in Industry" Abacus Press Limited.

[4]. Hubbard G. L and Denny V.E (1985) "International Journal of Heat and Mass Transfer" Vol 18 pp. 20 - 31

[5]. Mayes R. A (1983) "Handbook of Energy Technology and Economics" John Miley \& Sons Inc.

[6]. Daudas W. H. (1985) “Cement Data Book” P4 - 5. 